\title{
CRÍTICA JURÍDICA Y FILOSOFÍA POLÍTICA: REFORMAS LEGALES Y CAMBIO DE PARADIGMA
}

\section{Autor: Sergio Martin}

Tapia Argüello

Investigador doctoral, Centro de Estudios Sociales de la Universidad de Coímbra, Portugal. Correo electrónico: parin75@hotmail. com; tapiaarguello@derecho.unam.mx.

ORCID: https://orcid.org/0000-0001-9456-0620

decir, se pregunta por las causas del derecho; no por cómo se produce la dominación a

\author{
(Legal Critique and Political Philosophy: Legal \\ Reforms and Paradigm Shift)
}

Fecha de recepción: 20 de agosto de 2020

Fecha de aceptación: 28 de octubre de 2020

La presente investigación pretende ofrecer fundamentos para contestar a otra pregunta: “¿por qué el derecho dice eso que dice y no otra cosa?". Es través del mismo.

Resumen: Las transformaciones en el derecho son presentadas, desde las visiones tradicionales, como resultado de elementos culturales o bien, adaptaciones del derecho a las "condiciones sociales". Al hacer esto, estas visiones privilegian una comprensión parcializada del derecho, la sociedad y su relación. Con la finalidad de analizar la relación entre las ideas de flexibilización y derecho, el presente trabajo desarrolla un análisis de las transformaciones paradigmáticas del derecho moderno.

Palabras clave: Crítica Jurídica Latinoamericana; Paradigma jurídico; Filosofía política; Filosofía del derecho; Transformación del Derecho.

Abstract: Traditional theories shows the legal transformations as the result of cultural elements, as well as adaptations of the legal system to the "social reality". In this sense, they reproduce a reductive discourse about the law, the society and its relations. The present paper analyzes the paradigmatic transformations of law to understand the relation between the ideas of flexibilization and law.

Keywords: Latin American Critical Legal Thinking; Legal paradigm; Political philosophy; Philosophy of Law; Legal Transformation.

Esta obra está bajo licencia de 


\section{Introducción}

A Igunas visiones tradicionales ${ }^{1}$ reproducen, de una manera sistemática, un discurso profundamente fetichista sobre el derecho. Ya sea que articulen una visión que parte de ciertos principios epistémicos para construir una "clausura operacional" 2 de la sociedad y aquello que se considera sus elementos, o bien, que establezcan una separación, que presentan como temporal, sobre estos temas, 3 la división entre derecho y sociedad es, en muchos sentidos, un elemento común de dichas posturas.

A pesar de que en algunos momentos se presenta como una decisión metodológica necesaria, la división entre derecho y sociedad puede generar una comprensión incompleta de ambos conceptos y con ello, un sesgo de simplificación auto recursivo. ${ }^{4}$ Al separar la "sociedad" y el "derecho" de esta manera, es posible construir en abstracto aquello que se entiende como "lo jurídico", dejando fuera las relaciones de poder, los elementos culturales y psicológicos de su ejercicio e incluso su realidad material. Es decir, el análisis puro del derecho, puede fácilmente derivar en la idea de un derecho puro, alejado de las condiciones políticas, económicas, culturales e incluso psicológicas, que le articulan. ${ }^{5}$

Por el contrario, una visión crítica deberá abordar este tema de una manera distinta, que, a efectos del presente trabajo, podría plantearse bajo dos ideas; la primera, que no existe una distinción ontológica entre las normas que articulan y dotan de sentido a una sociedad y dicha sociedad; la segunda, que para conocer de manera adecuada la experiencia jurídica de la modernidad, la distinción disciplinar que separa al análisis normativo técnico de otras áreas, puede resultar no sólo incompleta, sino incluso en ocasiones perjudicial.

La primera afirmación sobre la inexistencia de una distinción entre las normas de una sociedad (sean estas o no calificadas como derecho) y dicha sociedad, puede ser constatada de una forma relativamente sencilla. Después de todo, es necesario recordar, sólo a través de la existencia compartida y la aceptación, ya táctica o explícita de un conjunto de normas, es que un grupo humano se convierte efectivamente en una sociedad. ${ }^{6}$ Del mismo modo, estas tan sólo tienen sentido (e incluso hacen sentido) si existe un proceso de socialización común. ${ }^{7}$ Asi, no resulta extraño observar que

1.- La distinción entre teorías tradicionales y teorías críticas en el derecho resulta un tema demasiado extenso para las intenciones del presente trabajo. Debido a ello, se indicará simplemente que se entiende por "teorías tradicionales" a aquellas que asumen la existencia de un núcleo incuestionable de postulados iniciales para la comprensión del fenómeno jurídico, ya de manera implícita o explícita, y como críticas, a las que intentan cuestionar no los límites de dichos postulados iniciales, sino su existencia misma. Para un análisis de estas categorías así como los elementos que las diferencian, cfr. Tapia Argüello, Sergio Martín, “Una breve (y quizá personal) introducción a la Crítica Jurídica", en Tapia Argüello, Sergio Martín; Gómez Martínez, Diego León y Solano Paucay, Vicente, Estudios Jurídicos Críticos en América Latina, Volumen 1, Cali, Diké- Universidad Santiago de Cali, 2019, pp. 127- 160.

2.- E.g. Luhmann, Niklas, El derecho de la sociedad, Madrid, Universidad Iberoamericana- Herder, 2008.

3.- Holloway, John, “El estado y la lucha cotidiana”, en Cuadernos políticos, número 24, México, Era, abril-junio 1980, p. 17

4.- Cfr. Kennedy, Duncan, “La educación legal como preparación para la jerarquía” en Courtis, Christian (comp.), Desde otra mirada, textos de teoría crítica del derecho, Buenos Aires, Eudeba, 1999.

5.- Tapia Argüello, Sergio Martín, "Poder como dominación. Una reducción útil para las visiones tradicionales del derecho", Derecho y Crítica Social, 1 (1), 2015, pp. 411- 446.

6.- Kelsen, Hans, Teoría General de las Normas, México, Trillas, 2010.

7.- Grossi, Paolo, "¿Justicia como ley o ley como justicia? Anotaciones de un historiador del derecho, Mitología jurídica de la modernidad, Madrid, Trotta, 2003. 
esta idea en corrientes tan distintas como el pensamiento kelseniano clásico, ${ }^{8}$ la visión específica de la Crítica Jurídica Latinoamericana, ${ }^{9}$ e incluso, el acercamiento marxista del derecho. ${ }^{10}$

Esto no significa, al menos para la teoría crítica, que se proceda a una suerte de naturalización del derecho, una eternización transhistórica que, a partir de la afirmación de que no es posible hacer una separación entre el derecho y la sociedad en que éste se articula, homologue el fenómeno general de la normatividad y la forma históricamente particular del derecho. El derecho es un sistema normativo de tipo jurídico, que al igual que muchos otros que han existido y que existen igualmente ahora, tiene una dimensión histórica concreta: la de la modernidad capitalista. ${ }^{11}$ Se trata de una forma específica de las relaciones sociales, ${ }^{12}$ que al presentarse bajo la forma de un "sistema" de normas, regulan la conducta humana de una manera centralizada y heterónoma. ${ }^{13}$

Si bien la forma específica del derecho occidental moderno se ha convertido, en la forma hegemónica de la regulación social de nuestros tiempos, esto no significa que se trate de la única, ${ }^{14}$ ni que esta haya estado siempre presente. ${ }^{15}$ De la misma manera, que el derecho exista sólo dentro de un marco histórico determinado, ${ }^{16}$ no significa que en otros periodos no existieran normas sociales de convivencia, incluso sistemas institucionalizados de punición y castigo, sino que las características de esos sistemas han sido tan diferentes a la heteronomía externa centralizada del derecho occidental moderno, que la única manera en que es posible llamarles "derecho", es mediante una analogía funcional; ${ }^{17}$ una metáfora que aunque debe ser reconocida como tal, resulta fácilmente olvidada en la actualidad.

Uno de los mecanismos para este olvido, que después de todo, se convierte en uno de los mitos iniciáticos de la ideología jurídica de las visiones tradicionales, puede ser observado, exactamente, en la artificial separación del derecho del resto de las actividades humanas. Si éste no es más que una forma específica de las relaciones sociales, lo idóneo sería, entonces analizar su existencia de una manera conjunta y multidimensional, algo que si bien es constantemente mencionado, resulta, en las prácticas de las universidades, bastante lejano.

En este sentido, el presente trabajo pretende realizar un acercamiento amplio, que salga más allá de lo que se considera en muchas ocasiones el dominio exclusivo de la "ciencia jurídica", o quizá mejor dicho, de las ciencias jurídicas, para observar, igualmente desde parámetros que

\footnotetext{
8.- Kelsen, Hans, Teoría general del derecho y del Estado, México, Universidad Nacional Autónoma de México, 2008.

9.- Correas, Oscar, Introducción a la crítica del derecho moderno. Esbozo, Puebla, Cajica, 1982.

10.- Poulantzas, Nicos, Hegemonía y dominación en el Estado moderno, Córdoba, Pasado y presente, 1969.
}

11.- E.g. Pashukanis, Evgeny B., Teoría general del derecho y el marxismo, México, Grijalbo, 1976. Para el que es quizá el más conocido teórico marxista del derecho, éste sistema normativo encuentra su horizonte de existencia exclusivamente en la sociedad capitalista moderna. Fuera de ella, y en el futuro posible que podría existir dentro del modo de producción comunista, el derecho como tal dejaría necesariamente de existir, lo que no significa, de forma alguna, la inexistencia de normas.

12.- Miaille, Michel, "La especificidad de la forma jurídica burguesa”, Crítica Jurídica en Francia, Puebla, Universidad Autónoma de Puebla, 1986.

13.- Para ver a profundidad las características de esta afirmación, cfr. Tapia Argüello, Sergio Martín, “El papel del derecho como revolución cultural", Crítica Jurídica, Revista latinoamericana de política, filosofía y derecho, 32, 2011, pp. 151-59

14.- Algo que puede fácilmente observarse en la idea del pluralismo juridico. Cfr. Correas, Oscar, Pluralismo Jurídico, otros horizontes, México. Coyoacán, 2011.

15.- Cfr. Grossi, Paolo, “Más allá de la mitología jurídica de la modernidad”, Mitología jurídica de la modernidad, Madrid, Trotta, 2003.

16.- Cfr. Tigar, Michell y Levi, Madelaine, El derecho y el ascenso del capitalismo, México, Siglo XXI, 1986.

17.- Schiavonne, Aldo, lus, la invención del derecho en occidente, Buenos Aires, Adriana Hidalga, 2013. 
normalmente se identifican como parte de la "filosofía política" las transformaciones que se generan dentro del derecho.

\section{Paradigma y Derecho}

\subsection{La idea de paradigma jurídico}

Si, como se ha indicado, no es posible hablar de una continuidad histórica del derecho moderno respecto a otros sistemas normativos del pasado, o no al menos en un sentido evolutivo o desarroIlista como es planteado desde algunas visiones tradicionales, ${ }^{18}$ tampoco puede establecerse una continuidad homogénea dentro de la idea de derecho. Esto quiere decir, que el derecho se transforma de manera continua, modificando sus elementos en momentos históricos determinados.

En cierto modo esto resulta obvio; la más superficial revisión del derecho positivo, proporciona elementos para observar un constante cambio en los dispositivos normativos, se trate de leyes propiamente dichas o bien otra forma de mandatos específicos, y sus contenidos. No obstante, esta aparente mutabilidad presenta una diferencia respecto al cambio en los sistemas normativos del pasado, pues las transformaciones se desarrollan bajo reglas previas que son, igualmente, parte del sistema. Esto, que es un efecto de los procesos de centralización de la codificación, ${ }^{19}$ genera una suerte de continuidad diferenciada, antes que una transformación.

Hablar de discontinuidades del derecho en la modernidad, requeriría una modificación mucho más profunda que la transformación de una norma particular, o de formas particulares de regulación que fueran homologables. Como se ha mencionado, el derecho moderno presenta una pretensión universal, que permite diferencias internas localizadas de importancia:

Si por hipótesis un sistema jurídico nacional debe explicarse las relaciones sociales existentes en la formación socioeconómica de que se trate, si las relaciones sociales de dos formaciones socioeconómicas responde dominantemente al concepto de un mismo modo de producción, si este a su vez necesita y explica un modelo jurídico ¿no sería de esperar que los dos sistemas nacionales fueran iguales? (...) Como cualquiera sabe, la respuesta no es fácil. Y basta para probarlo remitirse a la experiencia de cualquier abogado: sin duda un jurista mexicano se sentirá en terreno conocido si se trata del derecho civil argentino y viceversa. Pero existen sectores jurídicos en aparentemente flagrante contradicción. ${ }^{20}$

\footnotetext{
18.- Un recurso utilizado de manera constante en las visiones que, pretendiendo una cierta "objetividad" o neutralidad, asumen la superioridad occidental, tanto como un conjunto, como de las partes que se asume, sólo podrían existir bajo occidente, como el derecho. Cfr. e.g. Weber, Max, "Introducción”, Ensayos sobre sociología de la religión, tomo 1, Madrid, Taurus, 1987.

19.- Puede observarse la importancia de esta idea en la elaboración del Código Civil de Napoleón, que pretendía la generación de un sistema normativo que fuera capaz no sólo de regular todos los aspectos de la vida, sino también, de hacerlo para siempre, basando sus propias transformaciones en reglas del sistema mismo. Cfr. Portalis, Jean Marie Ettiene, Discurso preliminar al código civil francés, México, Editorial Porrúa, 1998.
}

20.- Correas, Oscar, Sociología del derecho y crítica jurídica, México, Fontamara, 1998, p. 47. 
Observar dos normas que resulten contradictorias, ya sea temporal o espacialmente, no basta para indicar una "transformación" del derecho. En cuanto estas diferencias se articulen en un mismo modo de producción, incluso aunque existan aparentes contradicciones entre ellas, podrá hablarse de una continuidad del sistema normativo como conjunto. La reducción de la comprensión de las "transformaciones jurídicas" a modificaciones normativas específicas y claramente delimitadas dentro del mismo sistema, es efecto de la comprensión sesgada de ciertas visiones normativistas (aunque afortunadamente, no generalizada ni siquiera en estas corrientes).

Una visión amplia de la idea de transformación, requeriría entonces escapar de la tentación de asumir que los cambios jurídicos pueden entenderse exclusivamente desde modificaciones normativas (y más importante aún, desde interpretaciones específicas de esas modificaciones) para observar al derecho como parte del hacer social general y por lo tanto, el papel del derecho en el modelo de acumulación ${ }^{21}$ específico de una epoca.

Con este nombre llamamos a la forma en que el sistema de producción ha resuelto, en cada momento histórico determinado, el problema de la tendencia decreciente de la tasa de ganancia. ${ }^{22}$ Esto quiere decir, una manera específica, temporalmente delimitada, de existencia del modo de producción capitalista que conjunta un régimen de acumulación particular, una estabilización a largo plazo de las formas particulares de producción y consumo de una sociedad determinada, con un modo regulación específico, lo que significa la creación de distintos mecanismos de cohesión e integración social, ya sea mediante coerción o bien por interiorización y naturalización de principios y normas sociales de convivencia (que incluirán, abiertamente incluso, aquellas de consumo y producción que el sistema necesite).

Las modificaciones del modelo de acumulación implican una modificación total del modo de regulación, en algunos casos incluso sin modificar los dispositivos normativos de carácter general (piénsese por ejemplo, en las interpretaciones diferenciadas que se da a normas particulares en momentos distintos). A estos momentos de transformación, es posible llamarles cambios paradigmáticos del derecho, ${ }^{23}$ es decir, transformaciones radicales, no encaminada al cambio simple de los mandatos y normas, como forma particular, sino de la manera en que se entiende la idea de regulación, sus límites discursivos y la modificación del sentido común jurídico ${ }^{24}$ de la sociedad.

\subsection{El largo camino de los cambios paradigmáticos}

Contrario a lo que algunas visiones tradicionales insisten en presentar como un cierto esencialismo de "lo jurídico" que va permitiendo mutar ciertas formas secundarias dejando un núcleo que se presenta permanentemente igual -el viejo sueño napoleónico de una codificación capaz de regular de una vez y para siempre, todo asunto relacionado con el ser humano o bien, de proporcionar los elementos para la creación de dichas regulaciones- ${ }^{25}$ las grandes transformaciones

21.- Harvey, David, La condición de la posmodernidad, Madrid, Amorrortu, 2000, c. 7.

22.- Marx, Karl, El Capital. Crítica de la Economía Política, Tomo 1, México, Fondo de Cultura Económica, 2008.

23.- Tapia Argüello, Sergio Martín, "Crítica Jurídica y Derechos Humanos: Autonomía normativa, resistencia y Emancipación”, Revista Direitos Humans \& Sociedade, 1 (1), 2018, pp. 35- 37.

24.- Debemos observar como sentido común, la manera (un tanto sedimentaria) en que los discursos oficiales sobre el derecho, se materializan en la vida cotidiana de la gente, a través de prácticas comunitarias, saberes cotidianos y formas fragmentarias que se asumen "naturales" en un contexto determinado. Para ver el concepto, cfr. Gramsci, Antonio, "Cuaderno 1" en Cuadernos de la cárcel, Puebla, Ediciones ERA/Benemérita Universidad Autónoma de Puebla, 2001, pp.151-152.

25.- Portalis, Discurso preliminar al código civil francés, óp. cit. 
sociales modifican la manera en que se entiende no sólo el contenido normativo de los diferentes dispositivos, sino incluso el sistema mismo que dota de sentido a dichos ordenamientos.

Sin duda alguna, el elemento central de todo sistema normativo, al menos si dicho sistema se establece a sí mismo como jurídico, es decir si pretende mostrarse como heterónomo, externo y bilateral, ${ }^{26}$ se encuentra en la prohibición de conductas y la imposición de sanciones que permitan la regulación social de dicha comunidad. ${ }^{27}$ Esto tiene sentido; después de todo, las regulaciones sociales no tienen por intención inicial generar permisiones de algo que ya está previamente permitido, sino exactamente lo contrario: prohibir algo que antes no se encuentra regulado. ${ }^{28}$

Debido a ello, los procesos de centralización normativa que generaron la idea moderna de derecho, se centraron, especialmente, en la imposición, administración y creación de las penas, es decir, aquello que nosotros conoceríamos como "derecho penal".29 Existe abundante evidencia que indica que si bien el poder político siempre pretende establecer un sistema punitivo propio, pocas veces en la historia había intentado, de una manera sistemática y totalizante, la eliminación de la sanción legítima fuera de sus márgenes de actuación. ${ }^{30}$ Se trata de una transformación en la forma de legitimación del poder público, que recorre hacia un régimen burocrático de dominación y que pretende establecer el monopolio del uso de la fuerza legítima en el poder político. ${ }^{31}$ Es el nacimiento del estado moderno y sus formas particulares. ${ }^{32}$

De esta forma, la creación de un sistema penal único es uno de los primeros objetivos del surgimiento del estado. La eliminación de otras formas de punición, como la venganza privada (vendetta) y el castigo entre particulares, es precisamente el elemento distintivo que separa al

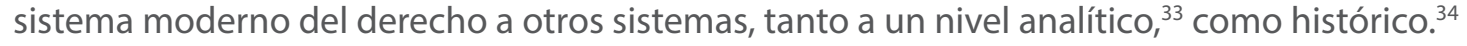

No es posible hablar de un camino único desarrollado de forma universal, para estos procesos. En cada región, en cada época, las maneras en que esta centralización se realizó, varió de formas, de tiempos e incluso, de pasos. Es una historia, como todas, llena de grandes temporalidades, de avances y retrocesos e incluso de contradicciones. La construcción lineal y unívoca con que algunas visiones construyen, de manera abstracta, ${ }^{35}$ una historia de las instituciones, tiene, en cada caso, asidero en las formas coloniales de construcción de conocimiento, que pretende generar universalizaciones ideales a partir de ejemplos concretos y reducir, de esta manera, la importancia de otras experiencias.

26.- Que consiste en la caracterización clásica del sistema normativo jurídico. Cfr. García Máynez, Eduardo, Introducción al estudio del Derecho, México, Porrúa, 2001.

27.- Kelsen, Hans, “El derecho como técnica social específica”, ¿Qué es justicia?, Barcelona, Planeta- Agostini, 1993.

28.- Tapia Argüello, “Poder como dominación. Una reducción útil para las visiones tradicionales del derecho”, óp, cit.

29.- Cfr. e.g. Thompson, Origenes de la ley negra, un episodio de la historia criminal inglesa, óp. cit.; Foucault, Vigilar y castigar. Nacimiento de la prisión, óp. cit.

30.- Grossi, "¿Ley como justicia o justicia como ley? Anotaciones de un historiador del derecho", óp. cit; Foucault, Historia de la sexualidad, óp. cit.

31.- Weber, Max, Economía y sociedad. Esbozo de sociología comprensiva, México, Fondo de Cultura Económica, 2008.

32.- Anderson, Perry, El estado absolutista, México, Siglo XXI, 2011.

33.- Kelsen, “El derecho como técnica social específica”, óp. cit.

34.- Foucault, Michel, Yo, Pierre Rivière habiendo degollado a mi madre, a mi hermana y a mi hermano..., Madrid, Maxi Tusquets, 2014.

35.- Cfr. Ross, Alf, "El concepto de validez y el conflicto entre el positivismo jurídico y el derecho natural”, El concepto de validez y otros ensayos, México, Fontamara, 2008 para observar estos problemas. 
En el tema que se trata, las distinciones surgieron desde el principio, con la separación entre un sistema oral y uno procesual- escrito que se convirtieron en las así llamadas "familias" del derecho occidental; por un lado, el derecho común (common law), que optó por la continuidad de las formas orales y por otro la familia romana o civilista, que desarrolló un sistema burocrático anclado en la palabra escrita. Esta separación, que origina una articulación diferenciada de los saberes jurídicos, dista mucho de ser una decisión neutra, sino que responde a condiciones y especialmente, necesidades, particulares:

El common law inglés no codificado ofrecía una notación alternativa de la ley, en ciertas maneras más flexible y menos principista - y por lo tanto más maleable para el "sentido común" de la clase dominante- $y$ en otras más accesible como un medio a través del cual podía expresarse el conflicto social, especialmente allí donde el sentido de "justicia natural" del jurado podía hacerse sentir. ${ }^{36}$

Puede parecer obvio que estas diferencias responden a condiciones particulares de cada uno de estos lugares; no obstante, el asumir que estas condiciones explican por sí mismas las divervencias, sería caer en un error bastante común. Como la vieja crítica ${ }^{37}$ a la escuela histórica alemana del derecho indica, pensar así sería estudiar a la historia sacándola al mismo tiempo de la historia. Las diferencias no pueden considerarse simplemente como resultado de "historias distintas" o no al menos, si mantenemos la idea de que el derecho moderno tiene, a diferencia de otros sistemas normativos, una pretensión de universalidad global, y que se configura como el primer sistema de regulación universal que surge en la modernidad occidental.

Partir de esta visión, que podría ser llamada "culturalista" sobre el derecho, tiene dos resultados: por un lado, se genera la legitimación del sistema tal y como existe, lo que incluye, los problemas sociales, económicos y de justicia y poder presentes, pues todo esto sería resultado de las condiciones históricas, que se volverían así, elementos inevitables y por lo tanto, una suerte de "leyes" en sentido natural que no podrían ser cuestionadas. Por otro, haría impensable la existencia de un sistema normativo de carácter universal, con posibilidades de traducciones interculturales ${ }^{38}$ que permitan observar la existencia de figuras comunes en sociedades diferentes.

El camino que asumió esta diferencia, como bien se establece en el párrafo citado anteriormente, se desarrolla a partir de la necesidad, en ciertos países, de una mayor flexibilidad para la conformación de un nuevo sentido común jurídico popular que permita las transformaciones requeridas tanto a nivel social, como económico, para lograr la articulación de un nuevo modo de producción. La necesaria inclusión al mercado de la tierra y el trabajo en la conformación del capitalismo moderno, uno de los temas más estudiados de los últimos doscientos años, ${ }^{39}$ se conjuntó, como necesidad general del sistema, con resistencias históricas concretas, para llevar a cabo esta división.

No se trata, como puede observarse, de tomar a la historia como un elemento independiente, ajeno, externo a las relaciones sociales; sino como una forma viva que se mantiene incluso en los

36.- Thompson, Origenes de la ley negra, un episodio de la historia criminal inglesa, óp. cit., p. 289.

37.- Marx, Karl, "Contribución a la crítica de la filosofía del derecho de Hegel. Introducción”, La cuestión judía (y otros escritos), Barcelona, Planeta- Agostini, 1994.

38.- Sa Santos, Sociología Jurídica Crítica. Por un nuevo sentido común en el derecho, Madrid, Trotta, 2009.

39.- E.g. Marx, El capital. Crítica de la Economía Política, Tomo 1, óp. cit; Polanyi, La gran transforamción, óp. cit.; Weber, Max, Historia económica general, México, Fondo de Cultura Económica, 2008. 
momentos de tensión. La protección de la propiedad privada, la prohibición de la colectivización laboral y gremial, la abolición de los fueros y la imposición de igualdad formal, se convirtieron en piedras de toque de este nuevo sistema, asumiéndose incluso, bajo un nuevo discurso: el de los derechos tal y como fueron planteados desde la versión liberal. ${ }^{40}$ Su universalización, incluso a través de mecanismos e instituciones contradictorios, muestra la existencia no de diversos sistemas normativos, sino de un sistema normativo general, que asume diversas formas, de acuerdo al contexto.

\subsection{La construcción del discurso moderno sobre el derecho}

La gran transformación de los sistemas punitivos a través de la centralización normativa, cumplía en el estado el viejo sueño del moderno Leviatán, ${ }^{41}$ En un inicio, el sistema no se separó mucho de las costumbres del pasado respecto a las formas de sanción, pero pronto, esto tuvo que cambiar. ${ }^{42}$ La búsqueda de una nueva forma de gubernamentalidad de la vida ${ }^{43}$ (y en otros sitios, de la muerte ${ }^{44}$ así como la transformación de los mecanismos de medición y observación de la realidad y el tiempo, ${ }^{45}$ requirieron una modificación de las sanciones y su justificación. ${ }^{46}$

El proceso de normalización que movió las penas del tormento de los cuerpos al disciplinamiento de las almas, ${ }^{47}$ fue impulsado por la necesidad de un sistema normativo que regulara de manera centralizada el trabajo activo, el ocio y principalmente, su división. La expansión del mundo en los siglos XV y XVI a través de las guerras de conquista que serían el origen de las ideas de tanto de América y Europa ${ }^{48}$ como de oriente y occidente, creó por primera vez en la historia, una sociedad global. ${ }^{49}$ Con ello, nacía también la necesidad de un sistema normativo anclado en principios universalizables, pero que al mismo tiempo permitiera la adaptación regional.

La configuración e imposición del nuevo sistema normativo, sólo era posible a través de un compromiso inter- clases, ${ }^{50}$ que integrara a los comerciantes y artesanos, vistos como marginales en el sistema de producción feudal, al resto de clases dominadas. ${ }^{51}$ Ello fue posible sólo a través

40.- E.g. Locke, John, Segundo ensayo sobre el gobierno civil, Madrid, Guernika, 2008.

41.- Hobbes, Thomas, Leviatán, o la materia, forma y poder de una república, eclesiástica o civil, México, Fondo de Cultura Económica, 1984

42.- Uno de los trabajos iniciales de este proceso, que vinculó la sistematización de las sanciones con la modificación de las penas, es el clásico Beccaria, Cesare, Tratado de los delitos y las penas, Madrid, Carlos III, 2015.

43.- Foucault, Michel, Genealogía del racismo, La Plata, Caronte, 1996.

44.- Mbembe, Achille, “Necropolitics”, Public Culture, 15 (1), 2003, pp. 11- 40.

45.- Ost, François, El tiempo del Derecho, México, Siglo XX, 2005.

46.- Cfr. Foucault, Vigilar y castigar. Nacimiento de la prisión, óp. cit.

47.- Foucault, Historia de la sexualidad I, óp. cit.

48.- Dussel, Enrique, "Europa, modernidad y eurocentrismo", La colonialidad del saber: eurocentrismo y ciencias sociales. Perspectivas latinoamericanas, Buenos Aires, CLACSO, 2000.

49.- Schmitt, Carl, El Nomos de la Tierra en el Derecho de Gentes del “Jus Publicum Europeum”, Buenos Aires, Struhart \& Cía, 2005.

50.- Como en otros momentos, cfr. Polanyi, La gran transformación, óp. cit.

51.- Tigar y Levi, El derecho y el ascenso del capitalismo, óp. cit. 
de la idea de la igualdad formal que articuló la necesaria destrucción de un sistema escalonado y diferenciado de regulaciones múltiples ${ }^{52}$ para encarar la existencia de un derecho centralizado, único y transversal. Esto generaba, al mismo tiempo, una igualación de estas clases a las dominantes, si bien esto sucedía sólo discursivamente.

Para lograr esto, se necesitaba un sustento ideológico propio. Inicialmente, se recurrió al naturalismo antiguo, de base teológica ${ }^{53}$ que fue pronto rechazado como fundamento debido, entre otras cosas, a su incompatibilidad con un sistema social de economía de mercado. Se requirió entonces un proceso de secularización del pensamiento ${ }^{54}$ que encontró en la idea de la razón ${ }^{55}$ la construcción de un ideal abstracto que permitiera la creación del nuevo sistema normativo. Así, el nuevo sistema se separa del "empirismo" basado en la vida social, para colocar como sustento último, a la razón humana para su construcción. ${ }^{56}$

De esta forma, el nuevo sistema se legitimará a través de dos frentes. Por un lado, se colocará a sí mismo como un sistema "más justo" basado en la idea de la igualdad formal. Por otro, se establecerá como mejor en cuanto es "racional". No resulta difícil observar que en la polisemia del concepto razón y sus derivados, existen posibilidad de flexibilidad ideológica, lo que permitió una aceptación mayor de la idea. ${ }^{57}$ Esto no sucedió, resulta necesario remarcarlo de una manera constante, porque dicho sistema fuera esencialmente mejor, sino porque claramente, esta ideología se adaptaba mejor, se desarrollaba de una forma más armónica, con la transformación social general a la que se dirigía el mundo. ${ }^{58}$ No se trata de una calificación de superioridad en términos morales, sino más bien de la aceptación de una mejor adaptabilidad al sistema social general y sus condiciones.

De esta forma, los límites de las normas de carácter penal, y con ello de las decisiones en materia penal, adquirieron límites específicos que no tenían antes. La prohibición de las penas corporales, de la destrucción del cuerpo y de los bienes ajenos (un elemento sumamente importante que requería igualmente, la separación del sujeto de aquello que eran los bienes, transmisible y como tales, no vinculados esencialmente a quien los ostenta en un momento determinado), el requisito de una correspondencia racional entre sanciones y culpas, se volvieron moneda corriente:

[...]una decisión jurídica es estrictamente racional si y sólo si 1) Respeta las reglas de la lógica deductiva (racionalidad L) ... 2) Respeta los principios de la racionalidad práctica (racionalidad D)... 3) Se adopta sin eludir utilización de alguna fuente del Derecho de carácter vinculante, 4) No se adopta sobre criterios (...) no previstos específicamente..$^{59}$

\footnotetext{
52.- Apreza Salgado et al., Derechos humanos, óp. cit.

53.- Vázquez, Entre la libertad y la igualdad. Introducción a la filosofía del derecho, óp. cit.

54.- Vigo, Rodolfo, “Prólogo", La injusticia extrema no es derecho (De Radbruch a Alexy), Buenos Aires, Astrea, 2004.

55.- Nino, Santiago, Introducción al análisis del derecho, Buenos Aires, Astrea, 2003, p. 29.

56.- Cfr. e.g. Kant, Immanuel, Principios metafísicos de la Doctrina del Derecho, México, Universidad Nacional Autónoma de México, 1968, p. 31.

57.- Tapia Argüello, Sergio Martín, “Derecho, modernidad y razón. Reformas y nuevo constitucionalismo en América Latina”, óp. cit.

58.- Horkheimmer y Adorno, Dialéctica de la ilustración, óp. cit.

59.- Atienza, Manuel, “Para una razonable definición de'razonable'”, Doxa, 4, 1987, p. 23.
} 
Estos criterios, vistos ahora como atemporales, son en muchas ocasiones entendidos, bien como los únicos posibles o bien, como los mejores que pueden existir. Un problema de generalización cultural que ignora las diferencias existentes y coloca en nuestros valores, una superioridad que difícilmente es comprobable de manera empírica fuera de los límites de nuestro propio marco de referencia ético. Esto no significa que no debamos defender la existencia de estos principios, sino que debemos comprender que su superioridad se da no de una manera esencial, sino relativa a aquello que nosotros mismos, como sociedad, somos y podemos ser. ${ }^{60}$

Como fundamento, la razón que se presenta no es pues, una razón genérica sino una particular forma de la misma, diseñada desde una ética particular dirigida al lucro, ${ }^{61}$ que parte de la "sistematización científica de la teoría del derecho, las instituciones del derecho formal y una judicatura ejercida por funcionarios especializados en derecho"62 como fundamento necesario y suficiente para la creación de un sistema normativo (moralmente) superior.

De esta forma, el naturalismo racionalista se vuelve la forma de legitimación del nuevo sistema, aunque pronto demostró una serie de problemas para su perfeccionamiento. Los principios morales contenidos en sus ideas, se vuelven demasiado peligrosas para mantenerse en el centro discursivo del derecho moderno. ${ }^{63}$ Es el mágico impasse que da preponderancia a la existencia del derecho positivo, el surgimiento del mandato de la obediencia a la ley en cuanto ley, por ser el mandato de la autoridad y no por anclarse en los principios de justicia que sirvieron para colocar a este nuevo sistema como universal.

De esta forma, los requisitos del nuevo sistema se colocan no sólo en la existencia de funcionarios profesionales, es decir, autoridades especializadas con competencias delimitadas dentro de ordenamientos normativos públicamente conocidos, sino también y especialmente, en la posibilidad de conocer de antemano las acciones posibles, potenciales y deseables, de dichas autoridades ante acciones concretas. Una capacidad de previsión que permita en cálculo de los efectos de nuestras acciones y por lo tanto, su análisis previo para la toma de decisiones concertadas:

El examen general de la especificidad jurídica- estatal de las sociedades occidentales actuales comenzará con el análisis del carácter particular que esos valores registren en nuestro tiempo. Un nuevo elemento se agrega, sin embargo, como factor de estructuración de esta especificidad actual: la necesidad de cálculo de previsión. ${ }^{64}$

De forma interesante, algunos autores aseguran que no toda forma de previsión de la ley, permite por sí misma, la característica calculabilidad requerida por la economía de mercado. ${ }^{65}$ Tan sólo una previsión capaz de transformarse cuantitativamente en términos, tiempos, objetos, y que al

\footnotetext{
60.- Chiassoni, Pierluigi, "Tres ejercicios para una crítica del objetivismo moral. Con una premisa sobre la grunfphilosophie" en Ferrer Beltrán, Jordi; y Ratti, Giovanni, El realismo jurídico genovés, Madrid, Marcial Pons, 2011 nos da un buen ejemplo de cómo rechazar el objetivismo moral no significa la imposibilidad de defender argumentativamente la postura relativa específica de quien lo hace.

61.- Weber, "Introducción", óp. cit.

62.- Habermas, Jürgen, Teoría de la acción comunicativa l: racionalización de la acción y racionalización social, Madrid, Taurus, 1999, pp. 213- 214.

63.- Correas, Oscar, "Los derechos humanos, entre la historia y el mito II", Crítica Jurídica, Revista latinoamericana de política, filosofía y derecho, 26, 2007.

64.- Poulantzas, Nicos, Hegemonía y dominación en el Estado moderno, óp. cit., p. 25.

65.- Cfr. Tapia Argüello, “Poder como dominación. Una reducción útil para las visiones tradicionales del derecho”, óp. cit.
} 
mismo tiempo, sea capaz de generar previsiones intercambiables en estos elementos, coincidiría con las necesidades del sistema. Quizá forzando un poco el argumento, las visiones marxistas encuentran en esta condición, la fuente de las características del sistema moderno de prisión, que establece tiempos y sanciones económicas como centro de la actividad punitiva moderna. ${ }^{66}$

La previsión, de esta forma, coloca en el centro del derecho penal, como se ha mostrado, el centro de la vida jurídica de las sociedades modernas, el principio de nulla poena sine lege, que contrario a lo que en muchas ocasiones se piensa, especialmente por su desarrollo en latín, es un aforismo extremadamente reciente. Su primer uso, se encuentra en una obra de principios del siglo XIX, Lehrbuch des gemeinen in Deutschland gültigen peinlechen Rechts (Lecciones de Derecho Penal vigente en Alemania) de Von Feuerbach, ${ }^{67}$ usándose por primera vez en un ordenamiento, hasta las reformas de 1813 en dicho país. ${ }^{68}$

Este ejemplo nos permite ver, así, dos cuestiones. La primera, que las grandes transformaciones del derecho moderno generaron una reconfiguración total del mundo jurídico, como parte al mismo tiempo, de una transformación del sistema general. La segunda, que esta transformación busca, como otras en el pasado, legitimarse mediante la supuesta antigüedad de sus postulados. Como otros sistemas jurídicos, el derecho moderno pretende colocarse a sí mismo como el fruto de un largo e ininterrumpido proceso de transformación que hunde sus raíces en tiempos ya perdidos. Es la construcción de una mitología jurídica que pretende colocarse así más allá de las posibilidades de la crítica. ${ }^{69}$

Con independencia de este hecho, el principio de legalidad y la exigencia del sistema moderno de la taxatividad y estricto derecho, generaron componentes esenciales del derecho moderno. Una diferencia que no fue inmediata y que permitió ciertas excepciones, como hemos visto, hasta el siglo XIX. La lenta transformación del que salía de la norma (lo normal en ese sentido) primero, en un loco o desviado ${ }^{70}$ y hasta la construcción moderna de la idea de delincuente ${ }^{71}$ fue progresiva, pero imparable. Casi un siglo después, encontramos los últimos resquicios del viejo sistema caer, inevitablemente, ante la positivización absoluta del formalismo:

Es incorrecta la afirmación corriente de acuerdo con la cual una cierta clase de conducta humana trae consigo una sanción jurídica porque tal conducta es antijurídica. Al revés: la conducta es antijurídica porque tiene como consecuencia una sanción. Desde el punto de vista de la teoría que tiene como exclusivo objeto el derecho positivo, no hay más criterio del acto antijurídico que el hecho de que la conducta sea condición de la sanción. No hay un acto antijurídico en si mismo. En la teoría penal tradicional se establece una distinción entre mala in se y mala prohibitia, es decir, entre las conductas que es mala en si misma y aquella que tiene tal carácter sólo en cuanto está prohibida por un orden

\footnotetext{
66.- Pashukanis, Teoría general del derecho y el marxismo, óp. cit.

67.- Terragni, Marco Antonio, Estudios sobre la parte general del derecho penal, Santa Fe, Centro de Publicaciones- Secretaría de Extensión de la Universidad Nacional del Litoral, 2000, p. 60.

68.- Wensel, Hans, Derecho penal. Parte general, Buenos Aires, Roque Depalma, 1956.

69.- Fitzpatrick, Peter, La mitología del derecho moderno, México, Siglo XXI, 2008.

70.- Thompson, Los orígenes de la ley negra. Un episodio de la historia criminal inglesa, óp. cit., pp. 240- 241.

71.- Foucault, Yo Pierre Rivier, habiendo degollado a mi madre, a mi hermana y a mi hermano..., óp. cit.
} 
social positivo Esta distinción no puede ser mantenida en una teoría del derecho positivo. La distinción es el elemento típico de la doctrina del derecho natural. Procede de una suposición - que no puede ser probada científicamente- según la cual ciertas formas de conducta humana son, por su misma naturaleza, antijurídicas. Sin embargo, la pregunta sobre si cierta conducta del hombre es antijurídica no puede ser contestada por un mero análisis de tal conducta; únicamente puede responderse sobre la base de un determinado ordenamiento legal. Una misma conducta puede ser antijurídica de acuerdo con el derecho de la comunidad A y no serlo de acuerdo con el de la comunidad B. Diferentes ordenamientos jurídicos de pueblos distintos han estigmatizado como antijurídicos a lo largo del tiempo, muy diferentes patrones de conducta. Es verdad que órdenes jurídicos diferentes del mismo nivel cultural coinciden en cierta medida al estigmatizar como antijurídicas ciertas formas de conducta; y que ciertos tipos de comportamiento son desaprobados no solamente por el derecho positivo, sino también por el sistema moral conectado con el mismo derecho. Tales hechos no justifican, empero, el concepto de mala in se. Además, es necesario separar el problema jurídico que consiste en saber cómo debe definirse el concepto de acto antijurídico dentro de una sociedad de derecho positivo, del problema político- moral, que estriba en determinar qué conducta debe el legislador justamente conectar con una sanción. Ciertamente el legislador tiene que considerar en primer lugar como perjudicial determinada clase de comportamiento, un malum, a fin de enlazar a éste una sanción. Antes de que la sanción sea establecida el comportamiento no tiene el carácter de malum en sentido jurídico, es decir, no es un acto antijurídico No hay mala in se, solo hay mala prohibitia, pues un comportamiento es malum sólo cuando es prohibitium. ${ }^{72}$

De esta forma, la conformación moderna del derecho penal, ha generado una serie de características que quienes se encuentran dentro de los límites culturales y temporales de su existencia, identifican como naturales: un sistema racional de normas articuladas por el estado, para regular la conducta externa del ser humano en la sociedad, mediante la imposición de sanciones previamente establecidas en una legislación.

\section{Flexibilidad y derecho}

\subsection{Las grandes transformaciones jurídicas}

En este sentido, si el derecho ha tenido grandes transformaciones paradigmáticas, debemos identificar que el momento actual representa con claridad todos los elementos para una de ellas.

La primera, que podría identificarse con el momento de la centralización normativa estatal y su universalización como sistema jurídico, se enmarcó dentro de una transformación total de 
las relaciones de producción, que anclaron y permitieron el fortalecimiento del capitalismo ${ }^{73}$ en el mundo occidental, primero y posteriormente, en todo el mundo. ${ }^{74}$ La segunda, que significó el cambio de la legitimación naturalista hacia la positivización total de las normas, ${ }^{75}$ representó un cambio ético y político que consolidó el estado de las cosas después de un largo proceso de reconfiguración jurídica, defendiendo la propiedad privada obtenida en el primer periodo y regulando los anteriormente abiertos mercados de la tierra y el trabajo.

Finalmente, una tercera gran transformación, se genera a través del cambio sufrido por el desarrollo de las tecnologías de la información, la reducción de la tasa de ganancia y la caída de los precios de petróleo que se dio a partir de la segunda guerra mundial. ${ }^{76}$ Se trata de un sistema nuevo, que debe ahora encontrar la manera de regular el trabajo bajo un esquema de alto consumo y que pretende la ruptura de los esquemas éticos anclados en narrativas universales (a favor de un relativismo cultural e incluso personal) y la reconfiguración del pacto político, basado todavía en los principios liberales del siglo XVIII. ${ }^{77}$ No se trata, como es posible imaginar, de las únicas reformas existentes en la manera en que el derecho (y los derechos) son entendidos y analizados, sino, podría decirse, tres diferentes procesos transformativos, que engloban diferentes modificaciones y pueden ser agrupadas bajo parámetros delimitados. ${ }^{78}$

Como en otros momentos, la reconfiguración actual pretende mostrarse como un cambio necesario, que no haría sino colocar "al derecho" en el mismo sentido que la sociedad se dirige. Se trata, por ejemplo, de la justificación que se ha dado para la reconfiguración del mundo de trabajo de manera sistemática, ${ }^{79}$ al menos desde las pugnas anti sindicalistas de Europa en la década de los $70^{\prime} \mathrm{s}^{80}$ y sus vertientes latinoamericanas, que obtuvieron resultados mucho más veloces a través de la violencia sistemática y totalmente antidemocrática del periodo de las dictaduras. ${ }^{81}$

Para lograr esto se necesitan crear, de forma artificial, una división entre las ideas de "derecho" y "sociedad",82 como si se tratara de objetos, cosas independientes que se unen, quizá incluso necesariamente. ${ }^{83} \mathrm{Al}$ establecer como entes separados a lo que no son sino diferentes formas de relaciones sociales, es posible fetichizar el proceso de transformación social, mostrarlo como resultado de fuerzas independientes, incluso ajenas y de esta manera, presentar la idea de que es imposible incidir en él, aunque claramente se haya hecho.

A través de esto, las soluciones a los problemas estructurales, elegidas siempre bajo criterios políticos e ideológicos específicos, son presentadas como neutras e incluso, en algunas ocasiones,

73.- Tigar y Levi, El derecho y el ascenso del capitalismo, óp. cit.

74.- Tapia Argüello, “El papel del derecho como revolución cultural”, óp. cit.

75.- Vigo, “Prólogo”, óp. cit.

76.- Harvey, La condición de la posmodernidad, óp. cit.

77.- Ramos Colas, "Ciudadano vs consumidor: significado del consumo en el postcapitalismo de Streeck”, óp. cit.

78.- Cfr. Kennedy, Duncan, Tres globalizaciones del derecho y del pensamiento jurídico, 1850- 2000, Bogotá, Universidad del Externado, 2015.

79.- Bensunsan, El modelo mexicano de regulación laboral, óp. cit.

80.- Holloway, La rosa roja de Nissan, óp. cit.

81.- Cfr. Klein, Naomi, La doctrina del shock, El auge del capitalismo del desastre, Madrid, Paidos, 2007.

82.- Correas, Introducción a la crítica del derecho moderno, óp. cit.

83.- Holloway, "El Estado y la lucha cotidiana", óp. cit. 
como naturales. Esto tiene claramente una intención, pues en muchas ocasiones, no hacen sino intentar repetir las viejas soluciones del pasado con mejores condiciones para alguna de las partes. En el caso del mundo del trabajo, que se mencionó anteriormente, la tendencia actual es el de la liberalización total del mercado de trabajo para colocar las relaciones jurídicas como acuerdos de voluntades, ${ }^{84}$ que colocaría el peso de las obligaciones en el trabajador, como sucedía en los inicios del proceso liberal.

La visión eminentemente revolucionaria de la acumulación originaria del capital ${ }^{85}$ se acompañó de la creación de las instituciones modernas del estado soberano, ${ }^{86}$ y contó, en ese sentido, con un derecho igualmente revolucionario. La centralización normativa, iniciada en los grandes poderes feudales por los últimos reyes absolutistas, ${ }^{87}$ fue parte sustancial de los intentos de mantener un control total de los procesos sociales. Su reutilización en la forma jurídica burguesa fue posible mediante una resignificación secular de discurso de justicia y un proceso constituyente de largo alcance.

En un segundo momento, cuando la nueva clase comerciante había ya logrado su solidificación, el giro epistémico hacia la reglamentación forzada hizo al panóptico ${ }^{88}$ y la triada representativa de la fábrica, la escuela y la prisión, ${ }^{89}$ a sus elementos centrales. Las leyes que crearon la propiedad y generaron la ruptura del viejo sistema feudal, fueron al mismo tiempo las leyes que disciplinaron al pueblo y establecieron un nuevo sentido común en él.

Mientras que estos elementos pueden ser observados de una manera constante, conservando las reminiscencias y persistencias de esos mecanismos incluso en nuestros tiempos, las formas más finas de dichos procesos no se darán sino hasta siglos después, a través de una lógica que encontrará en el modelo fordista de acumulación su cúspide:

Ante todo, la disciplina fordista era totalizante, dirigida a racionalizar todos los aspectos de la vida social, incluyendo muchos nunca antes sujetos a una organización deliberada. Animados por una pasión por el control, los gerentes de Henry Ford buscaron racionalizar no sólo la producción de fábrica, sino también la vida familiar y comunitaria de sus trabajadores, con el pretexto de que los hábitos de trabajo comenzaban en casa. Entre los años 1910 a 1930, de manera similar, los reformadores estadounidenses comenzaron a promover agencias municipales, estatales y federales orientadas hacia asegurar la protección y la salud pública. El mismo periodo vio la proliferación de los cuerpos codificados de los expertos en la racionalización social: manuales de crianza, manejo de la casa ("economía del hogar"), trabajo social (estudio de caso), psicoterapia (médica y popular), psicología industrial, sólo

84.- Cfr. Tapia Argüello, Sergio Martín, “Derecho laboral e ideología: el liberalismo y la regulación del trabajo en México”, Crítica Jurídica. Nueva época, 2, 2020.

85.- Marx, El capital, Crítica de la economía política, Tomo 1, óp. cit.

86.- Weber, Historia económica general, óp. cit.

87.- Anderson, El estado absolutista, óp. cit.

88.- Bentham, Jeremy, "Panopticon, or, the inspection house, \& C." en McLaighlin, Eugene; Muncie, John; Hughes, Gordon, Criminological Perspectives, Londres, SAGE, 2008, pp. 25- 32.

89.- Foucault, Vigilar y Castigar. Nacimiento de la prisión, óp. cit. 
para nombrar unos cuantos. Más tarde vinieron las agencias de control enfocadas especialmente en los grupos de edad (justicia juvenil) y del regimiento corporal (manuales de sexo, programas nutricionales y de acondicionamiento físico). Aparentemente, ninguna arena social estaba fuera de los límites de la campaña por someter todo al control racional. ${ }^{90}$

Así, el sistema penal que se configuró dentro del fordismo, contenía en sí los elementos éticos, políticos y las estructuras institucionales de esta reconfiguración. La eliminación de la justificación moral de las sanciones para la articulación de un sentido común de la mala prohibitia que se ha narrado ya, generó al mismo tiempo, la legitimación de un sistema eminentemente formalista con controles internos exclusivamente de congruencia, un tipo de positivismo ${ }^{91}$ que en no pocas ocasiones se utilizó incluso en contra de los deseos mayoritarios y los principios moralmente aceptados de una sociedad determinada.

Es posible decir, que la positivización internacional de los derechos humanos, puede ser visto como resultado de un conflicto entre estos procesos..$^{92}$ Si bien los acontecimientos de la segunda guerra mundial no acabaron con el sentido formalista de la creación normativa, a partir de él se generaron modificaciones profundas. Ante los enormes problemas de inexistencia de una norma legal válida y vigente para calificar los actos abiertamente genocidas del gobierno alemán, se dio una confrontación entre posturas que buscaban que estas fueran sancionadas. Por un lado, distintas visiones naturalistas buscaban la aplicación de una suerte de interpretación supra jurídica que eliminara el principio de taxatividad de la norma penal mediante una postura abiertamente intuitivista; ${ }^{93}$ por otro, las distintas teorías de la argumentación jurídica ${ }^{94}$ presentaban la idea de la textura abierta de las normas. Ni una ni otra, sin embargo, cuadraban con las formas fordistas de elaboración normativa.

La respuesta, que pareció una suerte de compromiso "de una sola vez" permitió la unión de las diferentes opciones existentes y al mismo tiempo, la construcción de algo distinto. A través de ella se permitió una lenta y progresiva transformación que incluía la idea de la argumentación para buscar la superación del positivismo excluyente y al mismo tiempo, la positivización de los derechos humanos, estableciendo para ellos un control de tipo formal que limitara sus elementos naturalistas. Esta modificación, sin embargo, será más adelante una de las puertas para la transformación definitiva del modelo fordista de acumulación mediante un modo de regulación distinto. Es uno de los múltiples procesos que llevará a la flexibilización.

90.- Fraser, Nancy, “¿De la disciplina hacia la flexibilización? Releyendo a Foucault bajo la sombra de la globalización”, Revista Mexicana de Ciencias Políticas y Sociales, 46 (187), pp. 20- 21, desde: https://doi.org/10.22201/fcpys.2448492xe.2003.187.42392, consultado el 20 de mayo de 2020.

91.- Bobbio, Norberto, El problema del positivismo jurídico, México, Fontamara, 2008.

92.- Tapia Argüello, Sergio Martín, El sistema internacional de protección de Derechos Humanos, México, Comisión de Derechos Humanos del Distrito Federal, 2013.

93.- Cuyo epítome puede encontrarse en la famosa "Fórmula Radbruch", cfr. Radbruch, Gustav, Introducción a la filosofía del derecho. México, Fondo de Cultura Económica, 2013.

94.- Meyer, Michel, "Prólogo a la edición española: Perelman y la retórica filosófica” en Perelman, Chaïm y Olbrechts Tyteca, Lucie, Tratado de la argumentación jurídica. La nueva retórica. Madrid: Gredos, 2013. 


\subsection{Los cambios del modelo fordista}

El caso de la relación entre el modelo de acumulación fordista y el derecho ha sido ya tratado de una manera amplia. ${ }^{95}$ Basta decir aquí que la transformación de este modelo de acumulación, que se instaló desde principios del siglo $\mathrm{XX},{ }^{96}$ intentó articular una respuesta sistémica a los retos desarrollados a nivel mundial durante las décadas de los sesenta y setenta. ${ }^{97}$ Aun cuando las formas de vida desarrolladas mediante el "estado de bienestar", la forma de organización político- económica por excelencia de este modelo, nunca pudieron ser llevadas a todo el mundo, ni siquiera en los países centrales, sus postulados dieron forma a un cierto sentido común, ${ }^{98}$ que llevó a nuestras naciones a intentar replicar el modelo mediante formas particulares y adaptadas a sus condiciones específicas.

Diversos acontecimientos posteriores a la segunda guerra mundial generaron problemas a estos intentos. La creación de la Organización de Países Productores de Petróleo (OPEP) llevó a una nueva dinámica en la regulación de los precios de petróleo; ${ }^{99}$ al mismo tiempo, la disminución de consumo y la crisis sistémica ${ }^{100}$ del trabajo vivo mostraron los problemas de un sistema que si bien dotaban de estabilidad laboral para unos cuantos, exigía el cumplimiento de horarios rígidos y actividades profundamente repetitivas, lo que derivaba en una cada vez menor capacidad creativa y con ello, de producción. ${ }^{101}$

La flexibilización surge así, como una respuesta a los múltiples y cada vez mayores problemas del sistema fordista de producción. La manera en que las relaciones sociales se reconfiguran en el nuevo modelo de producción permite modificar la manera en que se regulan las condiciones de trabajo, tanto en funciones como en horarios ${ }^{102}$ y al mismo tiempo, genera una nueva manera de entender al derecho y los derechos. ${ }^{103}$ Este proceso había sucedido ya en el pasado, como se ha indicado en el presente trabajo, y la manera en que se instauró el modo de regulación del fordismo no fue la excepción:

Durante un siglo, la dinámica de la sociedad moderna que se ha visto gobernada por un doble movimiento: el mercado se expandió de un modo continuo, pero este movimiento coexistió con un con-

95.- Cfr. e.g. Tapia Argüello, Sergio Martín, “El doble papel de los derechos humanos", Conocimiento y cultura jurídica, 5, 2011, consultado el 6 de mayo de 2020, desde: https://www.researchgate.net/publication/280815754_El_doble_papel_de_los_derechos_humanos.

96.- Habermas, Jürgen, Problemas de legitimación en el capitalismo tardío, Buenos Aires, Amorrortu, 1998.

97.- Harvey, La condición de la posmodernidad, óp. cit.

98.- Santos, Boaventura de Sousa, A crítica da razão indolente, contra o desperdício da experiencia, Santa Maria da Feira, Afrontamento, 2002 , pp. $65-70$.

99.- Harvey, La condición de la posmodernidad, óp. cit.

100.- Portantiero, Juan Carlos, "Gramsci y el análisis de la coyuntura (algunas notas)", Los usos de Gramsci, Buenos Aires, Grijalbo, 1999.

101.- Holloway, John, La rosa roja de Nissan, Montevideo, Compañero, 1992.

102.- De la Garza Toledo, Enrique, “La flexibilidad del trabajo en América Latina”, Tratado latinoamericano de Sociología del Trabajo, México. Universidad Autónoma Metropolitana- Siglo XXI, 2006.

103.- Tapia Argüello, Sergio Martín, “Los derechos sociales y el modelo de acumulación flexible en México, Dignitas, V, 2012. 
tramovimiento que controlaba esta expansión orientándola hacia determinadas direcciones. Este contramovimiento resultó de vital importancia para la protección de la sociedad, pero fue a la vez compatible, en último término, con la autorregulación del mercado $y$, por tanto, con el mismo sistema de mercado.

El sistema de mercado se desarrolló a saltos y a golpes, engulló el espacio y el tiempo y, al crear la moneda bancaria, produjo una dinámica hasta entonces desconocida. En el momento en el que alcanzó su máxima extensión, hacia 1914, cada una de las partes del globo, todos sus habitantes e, incluso, las generaciones venideras, las personas físicas, al igual que esos inmensos cuerpos imaginarios denominados compañías, quedaron integrados en su seno. Un nuevo modo de vida se adueñaba del planeta con una pretensión de universalidad sin precedentes desde la época en que el cristianismo había comenzado su andadura. Esta vez, sin embargo, el movimiento se situaba en un plano puramente material. Simultáneamente se desarrollaba no obstante un contramovimiento. No se trataba simplemente del habitual movimiento de defensa generado por una sociedad que se enfrenta con el cambio, era más bien una reacción contra una dislocación que atacaba a todo el edificio de la sociedad y que sería capaz de destruir la organización misma de la producción que el mercado había hecho nacer. ${ }^{104}$

\subsection{Las características del cambio de paradigma actual}

Como puede observarse en este ejemplo, la manera en que estos procesos se han dado en otros momentos históricos, se encuentra profundamente estudiada, ${ }^{105}$ por lo que, aunque los momentos de cambio de paradigma resulten peligrosamente ambiguos y ciegos, ${ }^{106}$ existen elementos para observar la manera en que estas rearticulaciones funcionan en momentos de crisis capitalistas, sean estas de consumo o bien de producción.

En un principio, podemos ver las transformaciones del este modelo. Bajo el nuevo modelo de acumulación, se genera una contracción de las funciones del estado, a través de procesos de tercerización de servicios públicos. ${ }^{107}$ Derivado de e ello, encontramos la disminución de personal burocrático y el uso, cada vez mayor, de herramientas electrónicas e informáticas. ${ }^{108}$ Se procura la flexibilización de labores, horarios y actividades, ${ }^{109}$ así como la transformación de los flujos de trabajo y existencias de mercancías. ${ }^{110}$

\footnotetext{
104.- Polanyi, Karl, La gran transformación: crítica del liberalismo económico, Barcelona, Virus, 2016, pp. 237- 238.

105.- De manera somera, puede mencionarse los trabajos de Foucault, Michel, Vigilar y Castigar, nacimiento de la prisión, México, Siglo XXI, 2008; Grossi, Paolo, "Códigos: algunas conclusiones entre dos milenios", Mitología jurídica de la modernidad, Madrid, Trotta, 2003; Thompson, E. P., Los orígenes de la ley negra. Un episodio de la historia criminal inglesa, Buenos Aires, Siglo XXI, 2011, así como Tigar y Levi, El derecho y el ascenso del capitalismo, óp. cit.
}

106.- Santos, A crítica da razão indolente, Contra o desperdício da experiencia, óp. cit.

107.- Harvey, David, The enigma of capital and the crises of capitalism, Londres, Verso, 2011.

108.- Castells, Manuel, La Era de la información 1: economía, sociedad y cultura. La Sociedad red, Madrid, Alianza, 2000.

109.- De la Garza, “La flexibilidad del trabajo en América Latina”, óp. cit.

110.- Coriat, Benjamín, Pensar al revés. Trabajo y organización en la empresa japonesa, México, Siglo XXI, 1993. 
Estos cambios se acompañan de una repolitización parcial del individuo, ${ }^{111}$ es decir la construcción de una nueva forma de subjetividad política que profundiza la visión individualista presente en el capitalismo, pero que se encamina a la construcción identitaria particularizada. Se trata de una forma de construcción social que impulsa la visión individualizada de existencia, en cuanto genera una incapacidad de unión con otros, pero que al mismo tiempo, impide activamente la toma de decisiones individuales de relevancia para la vida. Como es predecible, estas características conllevan la creación de instituciones jurídicas y sociales de nuevo cuño, ${ }^{112}$ que modifican la manera en que el derecho y los derechos pueden ser entendidos.

Un buen ejemplo para identificar la manera en que esta transformación funciona ahora, en nuestro país, pueda ser observado en el uso del concepto "austeridad"113 que recorre actualmente el discurso político tanto al interior del aparato estatal, ${ }^{114}$ como en el sentir popular de la población. ${ }^{115}$

El efecto de repolitización parcializada del individuo, genera una difuminación de las posibilidades de unión comunitaria ancladas en el trabajo (que pasa a ser vista como una actividad igual que muchas otras) y por lo tanto ensancha la distinción entre el funcionario, como trabajador estatal y el resto de trabajadores de la iniciativa privada. Con ello, se pretende colocar la idea de que el funcionario es algo distinto, que tiene la "obligación moral" de renunciar a sus derechos, convertidos discursivamente en "privilegios", con el fin de desempeñar mejor sus actividades. Al mismo tiempo, se establece un parámetro eminentemente económico para identificar lo bueno o malo que es un trabajo cualquiera.

El ciudadano, que no se entiende más como trabajador, sino que se desdobla en elementos distintivos de su propia personalidad de acuerdo a las actividades que realiza en el momento, no reconoce en el otro a alguien que, como él, se encuentra en esta relación constreñido por fuerzas similares. ${ }^{116}$ A través de la ruptura del ethos comunal del fordismo, encuentra frente a sí, dentro del modelo flexible a otro, un otro imposible de conocer y por lo tanto, de sentir como igual. ${ }^{117}$ Sorprende, en la experiencia práctica, que esto sucede incluso entre aquellos que desarrollan actividades similares, pues conocedores de las características implícitas, podría esperarse cierta empatía, que se imposibilita bajo una lógica de sociabilidad fragmentaria. Incluso en lo cercano, es imposible reconocer-se y reconocer al otro. La metáfora de la máscara que se usa para hablar en el derecho, ${ }^{118}$ se vuelve aquí entonces, una de Jano, que cambia de acuerdo a las circunstancias.

\footnotetext{
111.- Habermas, Problemas de legitimación en el capitalismo tardío, óp. cit.

112.- Tapia Argüello, Sergio Martín, “El papel del derecho como revolución cultural”, Crítica Jurídica, Revista latinoamericana de política, filosofía y derecho, 32, 2011, pp. 151-59.
}

113.- Cfr. Centeno García, Gerardo, “Can México learn from the European austerity? Legal considerations about the Ley Federal de Austeridad Republicana", Athens Journal of Law, 6, 2020, pp. 167- 190.

114.- E.g. Secretaría de la Función Pública, Llama Función Pública a aplicar Austeridad Republicana con reducción en el gasto operativo de la APF, desde: https://www.gob.mx/sfp/articulos/llama-funcion-publica-a-aplicar-austeridad-republicana-con-reduccion-en-elgasto-operativo-de-la-apf-240007, consultado el 07 de mayo de 2020.

115.- Redacción, "Más del 50\% de los mexicanos aprueban gobierno de AMLO, según encuestas". Animal Político, 29 de noviembre de 2019, desde: https://www.animalpolitico.com/2019/11/aprobacion-gobierno-amlo-encuesta-gabinete-comunicacion-estrategica/ consultado el 07 de mayo de 2020.

116.- Zizek, Slavoj, En defensa de la intolerancia, Barcelona, Público, 2010, pp. 41- 43.

117.- Levinas, Emmanuel, “Ética como filosofía primera”. Aparte Rei, 43, 2006.

118.- Tamayo y Salmorán, Introducción analítica al estudio del derecho, México, Themis, 2011. 
Así, la reforma que pretende establecer la "austeridad" como una obligación del trabajador del estado, reproduce en la lógica gubernamental, la modificación sufrida por las reformas correspondientes al artículo 123 Constitucional apartado A y la Ley Federal del Trabajo, que en su momento, generaron igualmente, la idea de que la "productividad" era una responsabilidad del trabajador privado y no de los poseedores de los medios de producción, a través de la creación de una nueva "cultura laboral".119 Por ello, las modificaciones a pensiones, las llamadas "reformas estructurales" y especialmente, la reforma educativa y el proceso de austeridad republicana, son un parte de un proceso conjunto de transformación del mundo del trabajo y su regalamentación.

Estos proceos constituyen un camino de disciplinamiento de las fuerzas de trabajo bajo una nueva lógica de producción ${ }^{120}$ que requiere el abandono total de los horarios fijos, los calendarios establecidos e incluso, de los descansos sistematizados. En el caso de la iniciativa privada, esto se resuelve mediante un discurso de productividad y conjunción de esfuerzos para el supuesto bienestar común (la nueva cultural laboral), mientras que en la función pública, se desarrolla a través de la idea de compromiso o deber de auto sacrificio para "responder a las necesidades" del ciudadano (la austeridad republicana). ${ }^{121}$

Este doble proceso, se acompaña de un desdoblamiento de las identidades que pueden asumirse en ellos. Como se ha mencionado, existe en la actualidad un proceso de repolitización parcializada de los individuos, que busca eliminar los referentes comunitarios del modelo fordista, para construir un ideario individualista de las posibilidades de exigencia de bienes, servicios y derechos. ${ }^{122}$ Esto significa no sólo una cada vez menor efectividad de las formas comunitarias de lucha (como el sindicato, las marchas o las organizaciones comunitarias), sino también el surgimiento de nuevas formas comunitarias o bien, la reinterpretación de las existentes, bajo una lógica individualista (ya sea que sean atendidas como si se trataran de un individuo o bien, como si se tratara simplemente de una unión de ellos). De esta forma, al exigir algo, una misma persona puede presentarse de maneras distintas ante diferentes instancias: usuario, ciudadano, socio, sujeto de derecho, consumidor, se vuelven personalidades que se utilizan de manera intercambiable ante exigencias específicas.

Esto dificulta la presentación conjunta de necesidades comunes, pero al mismo tiempo, separa al "usuario" del funcionario, generando una forma específica de relación donde puede comportarse como un "consumidor". Así, las partes internas de los sujetos políticos (el comunitario y el particular que es cada uno de los miembros de dicha comunidad), se enfrentan entre sí, convirtiéndose esta división en una medida más de control. ${ }^{123}$ El ciudadano se presenta ante el funcionario, el consumidor ante el asociado que tienen una obligación y una responsabilidad

119.- Bensusán, Graciela, El modelo mexicano de regulación laboral, México, Plaza \& Valdez, 2000, pp. 460- 464.

120.- Algo común en estos procesos. Cfr. Coriat, Benjamín, El taller y el cronómetro: taylorismo, fordismo y la producción en masa, México, Siglo XXI, 2008.

121.- De la misma forma, se genera una categoría intermedia: los derechos ciudadanos, que eliminan la universalidad formal de los derechos humanos y generan una diferenciación al interior de las sociedades bajo un requisito extraordinario anclado en los límites del estado nación. Si bien todos somos humanos en el sentido formal, no todos somos (ni podemos ser) ciudadanos de un estado concreto. De esta manera, se excluye a aquellos grupos humanos que los procesos de extractivistas requieren más vulnerables: migrantes, comunidades alejadas y no contactadas, así como temporalmente, a los menores de edad. Cfr. Ferrajoli, Luigi, “Derechos fundamentales", Derechos y garantías. La ley del más débil, Madrid, Trotta, 1999.

122.- Habermas, Problemas de legitimación en el capitalismo tardío, óp. cit.

123.- Ramos Colás, Álvaro, "Ciudadano vs consumidor: significado del consumo en el postcapitalismo de Streeck", Oximora. Revista Internacional de Ética y Política, 14, 2019, pp. 91-108 desde: https://doi.org/10.1344/oxi.2019.114.26641, consultado el 01 de julio de 2020. 
frente a ellos. Puede tratarse incluso de las mismas personas, pero asumen una postura diferente de acuerdo a la posición específica en que se desenvuelven.

Este proceso no surge de la nada, sino que se trata de la universalización de formas preexistentes a través de un proceso de localismo globlalizado, ${ }^{124}$ es decir, de la universalización de elementos concretos y específicos de una parte del mundo, mediante mecanismos de poder y articulaciones más efectivas con el modelo de producción.

Para el caso concreto, se sigue tanto la forma de organización de trabajo anclado en las visiones japonesas de la posguerra, principalmente el toyotismo y la configuración norteamericana de la propiedad. Al forzar la inclusión de la propiedad privada en distintos instrumentos de derechos humanos a nivel internacional e incluso en legislaciones nacionales, se genera una ruptura tanto teórica como práctica sobre los derechos, con una pretensión clara. Presentar los derechos patrimoniales como si derechos humanos, e permite la separación de la comunidad en entes individuales, los propietarios, y establece un carácter patrimonial sobre el resto de los derechos, que se poseen de manera particular. Esta forma resulta común en el ideario americano, como lo muestra el temor perpetuo desde los inicios de su sistema democrático: "(a) pesar del sufragio universal, los electores americanos se sentían impotentes ante los propietarios".125

Este proceso aparentemente contradictorio, de división y desdibujamiento, permite legitimar la aparición de entes e individuos particulares que medien en las actividades originalmente reservadas, en la historia de las sociedades modernas, al estado, como la cobertura de servicios e incluso la entrega de bienes que son considerados (o considerables) como derechos. Esta modificación trae aparejada un cambio estructural en el sentido del principio de bilateralidad: la desaparición de la obligación del estado, gracias al surgimiento de la prestación del servicio por parte de un particular. ${ }^{126}$

Si bien puede argumentarse que en teoría este cambio no modifica, de iure, las obligaciones del estado; resulta claro que permite y facilita el desvío de responsabilidades y demora la posibilidad de exigencia de cumplimiento de las mismas. De la misma manera que hace doscientos años habría sido imposible pensar en términos de "propiedad" de la manera en que se realiza en nuestros días, ${ }^{127}$ hace cincuenta jamás se habría pensado en la posibilidad de que particulares ingresaran a áreas específicas de la atención pública, como es habitual ya en la actualidad, ${ }^{128}$ incluso, en muchas ocasiones, con un discurso de legitimación claro.

Como parte de los procesos de privatización y reducción del estado, la procuración e impartición de justicia han sufrido igualmente, transformaciones. El arbitraje, la mediación, así como las medidas alternativas de resolución de conflictos, no son algo novedoso en la historia del derecho; incluso, algunas posturas, asumen que estas formas se encontraban profundamente enraizadas dentro de la articulación de las características que llevaron a la centralidad normativa del estado. ${ }^{129}$ El derecho no era sólo muchos derechos, de múltiples fuentes y con maneras complementarias de resolver los problemas internos y sus frecuentes contradicciones, sino también

124.- Santos, Boaventura De Sousa, La globalización del derecho, Bogotá, ILSA, 1998, p. 202.

125.- Polanyi, La gran transformación, óp. cit., p. 373.

126.- Harvey, La condición de la posmodernidad, óp. cit.

127.- Horwitz, Morton J, “El ascenso del formalismo jurídico”, Historias Críticas del Derecho, Bogotá, Siglo del Hombre EditoresUniAndes, 2017, p. 75.

128.- Harvey, David, The enigma of capital and the crisis of capitalism, óp. cit.

129.- Cfr. Tigar y Levi, El derecho y el ascenso del capitalismo, óp. cit. 
disponían de autoridades no reconocidas por el poder político, en cuanto él no era la fuente de toda potencial norma de estos sistemas. ${ }^{130}$

Resulta sintomático que estas instituciones hayan sobrevivido de maneras múltiples y variadas a la centralización normativa hasta inicios del modelo de acumulación fordista. Los relatos de la temprana edad moderna, que cuentan la historia de la centralización de la toma de decisiones generada con la existencia de jueces profesionales, ${ }^{131}$ funcionarios pagados por la corona cuya labor consistía en la interpretación normativa local, muchas veces confusa o incompleta y generar su homologación a través de la palabra del poder público, mantuvo sin embargo grandes espacios de excepción como su propia regla: la lex mercatoria sobrevivió no sólo a las codificaciones a través de la fuerza de su propio empuje, ${ }^{132}$ sino también y especialmente, a la existencia de condiciones comerciales que permitían la costumbre y la resolución "amistosa" de conflictos ${ }^{133}$ mediante autoridades reconocidas por el estado, pero que no formaban parte del mismo.

Igualmente, los fueros especiales, eliminados a través de la idea liberal de la igualdad formal ${ }^{134}$ y las reglamentaciones particulares contra asociaciones, como la Ley Chapellier en Francia o las Combination acts en Inglaterra, tuvieron que dar paso a otras formas, veladas, de regulación y reglamentación de las diferencias, generando espacios en que las soluciones amistosas y la mediación tomaban un claro cariz de mandato obligatorio para la comunidad. Si bien las presiones formuladas a través de la centralización de creación normativa que se generaron con el Código Napoleónico incidieron de manera dramática en estas instituciones, el simple reconocimiento por parte del estado, genera un proceso de subsunción formal ${ }^{135}$ de ellas al nuevo sistema, pero no su eliminación. Reminiscencias de estos elementos, pueden ser encontrados, igualmente, en la justicia laboral y agraria en nuestro país, así como en las múltiples prácticas comerciales a través de contratos y acuerdos en la práctica real del derecho privado. ${ }^{136}$

\section{A manera de conclusión}

Los ejemplos presentados hasta aquí nos ponen de manifiesto que el momento actual lleva a cabo un proceso de transformación radical que puede ser comprendido como un cambio de paradigma jurídico. Las formas fordistas de regulación social se encuentran en una reconfiguración que poco dejará de ellas. No es un camino corto, ni mucho menos lineal, pero al comprender la reconfiguración jurídica como una parte más de la transformación social del modelo de acumulación particular, permite observar que se trata de un proceso social de mutua reconfiguración.

En los periodos recientes de la historia, varias instituciones, formas y saberes jurídicos del pasado fueron ignorados, perseguidos, incluso negados. A la luz de las nuevas condiciones que se generan por la reconfiguración de las relaciones sociales, retoman cierta centralidad, acompañándose en no pocas ocasiones con nuevas instituciones y procesos.

130.- Grossi, "¿Justicia como ley o ley como justicia? Anotaciones de un historiador del derecho", óp. cit.

131.- Cfr. Thompson, Origenes de la ley negra, un episodio de la historia criminal inglesa, óp. cit.

132.- Polanyi, La gran transformación, óp. cit.

133.- Cfr. Tigar y Levi, El derecho y el ascenso del capitalismo, óp. cit.

134.- Apreza Salgado, Socorro; Tapia Argüello, Sergio Martín, Meza Flores, Jorge Humberto, Derechos Humanos, México, Porrúa, 2017.

135.- Marx, Karl, El capital, libro I capítulo IV (Inédito), México, Siglo XXI, 2011.

136.- Correas, Oscar, Crítica de la ideología jurídica. Ensayo sociosemiológico, México, Coyoacán, 2005. 
Uno de los elementos principales de una economía anclada en los principios fordistas, está en la existencia de un estado fuerte que cumpla dentro de los límites de la legitimidad institucional, ${ }^{137}$ con ciertos requisitos mínimos de predictibilidad, razonabilidad y jerarquización. ${ }^{138}$ El derecho social, un tipo nuevo de articulación de las relaciones jurídicas, consiste en una ampliación de los márgenes de lo legal, que requiere, en este sentido, de cierta flexibilidad. Pero fuera de esta idea, el surgimiento de una teoría dura del monismo jurídico, anclado en el formalismo extremo del positivismo excluyente ${ }^{139}$ comenzó a desarrollarse como la normalidad jurídica. ${ }^{140}$

Estas características: un sistema normativo monista, anclado en la legitimidad de un sistema centralizado de toma de decisiones por parte del poder político por medio de la razonabilidad, la predictibilidad y la jerarquización, parecen, para las y los abogados contemporáneos, tan antiguos como la existencia misma de las normas, ${ }^{141}$ basta remontarse a los albores del siglo XX, para encontrar acaloradas discusiones sobre su fundamentación y legitimidad. ${ }^{142}$ Responden a un momento específico del derecho, un paradigma jurídico que para quienes asistimos este momento de superposición, es aún, en muchos casos, el sentido común jurídico que entendemos como natural.

No se trata de algo extraño, sino de una estrategia común en la conformación de nuevos sistemas normativos; en otros momentos, bajo otras miradas, otras formas particulares, tanto de este sistema como de otros, se han revestido igualmente de un aura de eternidad, cuando no pasaban de contar con una historia mínima, en muchas ocasiones más mítica y metafórica que real. ${ }^{143}$ Para conseguirlo, en cada ocasión, habían necesitado una reconfiguración social tremenda, en muchas ocasiones violenta, ${ }^{144}$ para la conformación de una nueva hegemonía. ${ }^{145} \mathrm{El}$ contexto mexicano puede fácilmente ver esto dentro de su propia historia.

Los elementos mencionados hasta aquí: la inclusión de los derechos humanos como parte central de lo jurídico, la reconfiguración de las relaciones laborales y su regulación, la inclusión de nuevas instituciones como la mediación, se acompañaron, como se ha mencionado, de una transformación de las necesidades del espacio central del derecho moderno: la imposición de sanciones de tipo penal. Múltiples problemas alcanzaron este rubro, ${ }^{146}$ que hicieron cada día más patente la necesidad de una reforma operativa, que se adaptara a las formas flexibles del modelo posfordista en el derecho penal y al mismo tiempo, generara las condiciones mínimas para el cumplimiento de las exigencias internas y externas de legitimidad institucional.

137.- Habermas, Problemas de legitimidad en el capitalismo tardío, óp. cit.

138.- Weber, “Introducción” óp. cit

139.- Cfr. Vázquez, Rodolfo, Entre la libertad y la igualdad. Introducción a la filosofía del Derecho, México, Colofón- Trotta, 2011.

140.- Correas, Oscar, "El pluralismo jurídico. Un desafío al Estado contemporáneo”, Revista mexicana de Ciencias Políticas y Sociales, 41 (168), 1997, pp. 91-98.

141.- Cfr. Tapia Argüello, “Derecho, modernidad y razón. Reformas y nuevo constitucionalismo en América Latina”, óp. cit.

142.- Un buen ejemplo, se encuentra en los sustentos ideológicos, sociales y éticos que el positivismo durkheimiano presentó a la idea del derecho. Cfr. e.g. Duguit, Leon, Las transformaciones generales del derecho privado desde el código de Napoleón, México, Coyoacán, 2006.

143.- Cfr. Schiavonne, lus, la invención del derecho en occidente, óp. cit, pp. 11- 17.

144.- Polanyi, La gran transformación, óp. cit.

145.- Cfr. Gramsci, Antonio, Notas sobre Maquiavelo, sobre política y sobre el Estado Moderno, México, Juan Pablos Editores, 1975; Tapia Argüello, “Poder como dominación. Una reducción útil para las visiones tradicionales del derecho”, óp, cit.

146.- Fix Fierro, Héctor, Flores, Julia Isabel; López Ayllón, Sergio y Valadéz, Diego, Encuesta Nacional de Cultura Constitucional: legalidad, legitimidad de las instituciones y rediseño del Estado, México, IFE, IIJ- UNAM, 2011. 
En este sentido, la reforma constitucional en la materia iniciada en 2008, generará un sistema mixto que, sin asumir las posiciones de la familia del common law, renuncie a los principios desarrollados por el sistema fordista a través de la versión local, el así llamado estado desarrollista ${ }^{147}$ dentro de nuestro sistema: la existencia de un sistema inquisitorial de investigación, la articulación de largos y pesados procesos con etapas procesales rígidas, la imposibilidad formal (aunque no material) de acuerdos extra- institucionales y la burocratización excesiva, misma que se confunde, dentro de dicho modelo, como el único camino para lograr un verdadero "formalismo". 148

La respuesta por su parte, busca generar una nueva forma de interpretar la finalidad de la pena, ${ }^{149}$ que esté acorde con una ética del trabajo y la vida comunitaria distinta, que profundiza, como se ha hablado, una percepción eminentemente individualista de la socialización (y que en ocasiones, genera a través de ello, un modelo de relativismo subjetivista extremo); se permite la flexibilización procesal y la simplificación de las formas, a través tanto de la creación de nuevos mecanismos e instituciones, como por la modificación de los principios rectores del proceso legal.

Contrario a la idea dominante, estas transformaciones no se generan como "resultado" de una transformación cultural de nuestras sociedades, ni siquiera, como algunas visiones mecanicistas suelen presentar, son resultado de transformaciones materiales ajenas al derecho mismo (como una suerte de objeto externo, incluso instrumentalizable), sino que son formas particulares de la transformación material general (es decir, económico- política, pero al mismo tiempo necesariamente cultural y social) del modo de producción de nuestras sociedades. A lo largo de distintos contextos, ésta tendrá características distintas, pero esto se debe no a características esenciales, sino a las condiciones concretas de las relaciones de poder en cada lugar y momento determinado. Por ello, contra la simplificación que se presenta en muchas ocasiones como resultado de una división disciplinar, resulta necesario recordar la riqueza de la realidad social que nos rodea.

\section{Bibliografía}

Anderson, Perry, El estado absolutista, México, Siglo XXI, 2011.

Apreza Salgado, Socorro; Tapia Argüello, Sergio Martín, Meza Flores, Jorge Humberto, Derechos Humanos, México, Porrúa, 2017.

Atienza, Manuel, "Para una razonable definición de 'razonable"', Doxa, 4, 1987.Beccaria, Cesare, Tratado de los delitos y las penas, Madrid, Carlos III, 2015.

147.- Eslava, Luis, "El estado desarrollista: independencia, dependencia y la historia del Sur". Derecho de estado, 43, 2019.

148.- Como modelo de regulación de la vida social, el fordismo privilegió el uso de los recursos públicos con la finalidad de generar estabilidad laboral, empleo pleno e inversión en infraestructura. Esto llevó a un problema cada vez mayor tanto en el sistema de pensiones como en el ingreso laboral privado, lo que derivó en una presión en aumento para el empleo público, con un aumento de la burocracia. En países periféricos, este problema se agudizó, debido a que si bien existió un aumento exponencial en términos absolutos en indicadores educativos, no existía un mercado inicial privado lo suficientemente fuerte que pudiera absorber el excedente de trabajadores calificados. Debido a ello, los problemas de burocratización se presentaron a un ritmo mayor, llevando a un colapso mucho más apurado del sistema, incluso antes de que pudiera lograr una cierta estabilización de base. De esta manera, los problemas de los países centrales se replicaron en nuestros países, sin lograr incluso las ventajas que el sistema les había permitido (como el ingreso mínimo vital o la seguridad social generalizada, que nunca, en ningún sitio, universal). Al lado de este problema, debemos recordar que la existencia de relaciones desiguales de poder entre los países, llevó a que los países centrales utilizaran mecanismos extractivistas cada vez mayores hacia la periferia, agudizando estos problemas en dichas naciones con la finalidad de reducir la presión en sus propios territorios.

149.- Gómez Pérez, Mara, "Los derechos humanos en las cárceles y centros de reclusión penitenciaria de México" en García Ramírez, Sergio e Islas de González Mariscal, Olga, Evolución del sistema penal en México. Tres cuartos de siglo, México, UNAM- INACIPE- IIJ, 2017, pp. 77- 98. 
Bentham, Jeremy, "Panopticon, or, the inspection house, \& C." en McLaighlin, Eugene; Muncie, John; Hughes, Gordon, Criminological Perspectives, Londres, SAGE, 2008Bensusán, Graciela, El modelo mexicano de regulación laboral, México, Plaza \& Valdez, 2000.

Bobbio, Norberto, El problema del positivismo jurídico, México, Fontamara, 2008.

Castells, Manuel, La Era de la información 1: economía, sociedad y cultura. La Sociedad red, Madrid, Alianza, 2000.

Centeno García, Gerardo, "Can México learn from the European austerity? Legal considerations about the Ley Federal de Austeridad Republicana", Athens Journal of Law, 6, 2020, pp. 167- 190.

Chiassoni, Pierluigi, "Tres ejercicios para una crítica del objetivismo moral. Con una premisa sobre la grunfphilosophie" en Ferrer Beltrán, Jordi; y Ratti, Giovanni, El realismo jurídico genovés, Madrid, Marcial Pons, 2011.

Coriat, Benjamín, El taller y el cronómetro: taylorismo, fordismo y la producción en masa, México, Siglo XXI, 2008.

Coriat, Benjamín, Pensar al revés. Trabajo y organización en la empresa japonesa, México, Siglo XXI, 1993.

Correas, Oscar, Crítica de la ideología jurídica. Ensayo sociosemiológico, México, Coyoacán, 2005. Correas, Oscar, "El pluralismo jurídico. Un desafío al Estado contemporáneo", Revista mexicana de Ciencias Políticas y Sociales, 41 (168), 1997.

Correas, Oscar, Introducción a la crítica del derecho moderno. Esbozo, Puebla, Cajica, 1982.

Correas, Oscar, "Los derechos humanos, entre la historia y el mito II", Crítica Jurídica, Revista latinoamericana de política, filosofía y derecho, 26, 2007.

Correas, Oscar, Pluralismo Jurídico, otros horizontes, México. Coyoacán, 2011.

Correas, Oscar, Sociología del derecho y crítica jurídica, México, Fontamara, 1998.

De la Garza Toledo, Enrique, "La flexibilidad del trabajo en América Latina", Tratado latinoamericano de Sociología del Trabajo, México. Universidad Autónoma Metropolitana- Siglo XXI, 2006.

Duguit, Leon, Las transformaciones generales del derecho privado desde el código de Napoleón, México, Coyoacán, 2006.

Dussel, Enrique, "Europa, modernidad y eurocentrismo", La colonialidad del saber: eurocentrismo y ciencias sociales. Perspectivas latinoamericanas, Buenos Aires, CLACSO, 2000.

Eslava, Luis, "El estado desarrollista: independencia, dependencia y la historia del Sur". Derecho de estado, 43, 2019.

Ferrajoli, Luigi, "Derechos fundamentales", Derechos y garantías. La ley del más débil, Madrid, Trotta, 1999.Foucault, Michel, El orden del discurso, Buenos Aires, Tusquets, 1992.

Fitzpatrick, Peter, La mitología del derecho moderno, México, Siglo XXI, 2008.

Fix Fierro, Héctor, Flores, Julia Isabel; López Ayllón, Sergio y Valadéz, Diego, Encuesta Nacional de Cultura Constitucional: legalidad, legitimidad de las instituciones y rediseño del Estado, México, IFE, IIJ- UNAM, 2011.

Foucault, Michel, Genealogía del racismo, La Plata, Caronte, 1996.

Foucault, Michel, Historia de la sexualidad I: La voluntad de saber, México, Siglo XXI, 2012.

Foucault, Michel, Vigilar y Castigar, nacimiento de la prisión, México, Siglo XXI, 2008;

Foucault, Michel, Yo, Pierre Rivière habiendo degollado a mi madre, a mi hermana y a mi hermano..., Madrid, Maxi Tusquets, 2014.

Fraser, Nancy, "¿De la disciplina hacia la flexibilización? Releyendo a Foucault bajo la sombra de la globalización", Revista Mexicana de Ciencias Políticas y Sociales, 46 (187), pp. 20- 21, desde: https://doi.org/10.22201/fcpys.2448492xe.2003.187.42392, consultado el 20 de mayo de 2020. García Máynez, Eduardo, Introducción al estudio del Derecho, México, Porrúa, 2001.

Gómez Pérez, Mara, "Los derechos humanos en las cárceles y centros de reclusión penitenciaria 
de México" en García Ramírez, Sergio e Islas de González Mariscal, Olga, Evolución del sistema penal en México. Tres cuartos de siglo, México, UNAM- INACIPE- IIJ, 2017.

Gramsci, Antonio, "Cuaderno 1" en Cuadernos de la cárcel, Puebla, Ediciones ERA/Benemérita Universidad Autónoma de Puebla, 2001.

Gramsci, Antonio, Notas sobre Maquiavelo, sobre política y sobre el Estado Moderno, México, Juan Pablos Editores, 1975.

Grossi, Paolo, "Códigos: algunas conclusiones entre dos milenios", Mitología jurídica de la modernidad, Madrid, Trotta, 2003.

Grossi, Paolo, “¿Justicia como ley o ley como justicia? Anotaciones de un historiador del derecho, Mitología jurídica de la modernidad, Madrid, Trotta, 2003.

Grossi, Paolo, "Más allá de la mitología jurídica de la modernidad", Mitología jurídica de la modernidad, Madrid, Trotta, 2003.

Habermas, Jürgen, Problemas de legitimación en el capitalismo tardío, Buenos Aires, Amorrortu, 1998. Habermas, Jürgen, Teoría de la acción comunicativa I: racionalización de la acción y racionalización social, Madrid, Taurus, 1999.

Harvey, David, La condición de la posmodernidad, Madrid, Amorrortu, 2000.

Harvey, David, The enigma of capital and the crises of capitalism, Londres, Verso, 2011.

Hobbes, Thomas, Leviatán, o la materia, forma y poder de una república, eclesiástica o civil, México, Fondo de Cultura Económica, 1984.

Horkheimer, Max y Theodor W. Adorno, Dialéctica de la ilustración, Madrid, Akal, 2007.

Horwitz, Morton J, "El ascenso del formalismo jurídico", Historias Críticas del Derecho, Bogotá, Siglo del Hombre Editores- UniAndes, 2017.

Holloway, John, Crack Capitalism, Londres, Verso, 2010.

Holloway, John, “El estado y la lucha cotidiana", en Cuadernos políticos, número 24, México, Era, abril-junio 1980.

Holloway, John, La rosa roja de Nissan, Montevideo, Compañero, 1992.

Kant, Immanuel, Principios metafísicos de la Doctrina del Derecho, México, Universidad Nacional Autónoma de México, 1968.

Kelsen, Hans, "El derecho como técnica social específica", ¿Qué es justicia?, Barcelona, PlanetaAgostini, 1993.

Kelsen, Hans, Teoría general del derecho y del Estado, México, Universidad Nacional Autónoma de México, 2008.

Kelsen, Hans, Teoría General de las Normas, México, Trillas, 2010.

Kennedy, Duncan, "La educación legal como preparación para la jerarquía" en Courtis, Christian (comp.), Desde otra mirada, textos de teoría crítica del derecho, Buenos Aires, Eudeba, 1999.

Kennedy, Duncan, Tres globalizaciones del derecho y del pensamiento jurídico, 1850- 2000, Bogotá, Universidad del Externado, 2015.

Klein, Naomi, La doctrina del shock, El auge del capitalismo del desastre, Madrid, Paidos, 2007. Levinas, Emmanuel, “Ética como filosofía primera”. Aparte Rei, 43, 2006.

Locke, John, Segundo ensayo sobre el gobierno civil, Madrid, Guernika, 2008.

Luhmann, Niklas, El derecho de la sociedad, Madrid, Universidad Iberoamericana- Herder, 2008.

Marx, Karl, "Contribución a la crítica de la filosofía del derecho de Hegel. Introducción", La cuestión judía (y otros escritos), Barcelona, Planeta- Agostini, 1994.

Marx, Karl, El Capital. Crítica de la Economía Política, Tomo 1, México, Fondo de Cultura Económica, 2008.

Marx, Karl, El capital, libro I capítulo IV (Inédito), México, Siglo XXI, 2011.

Mbembe, Achille, "Necropolitics", Public Culture, 15 (1), 2003, pp. 11- 40. 
Meyer, Michel, "Prólogo a la edición española: Perelman y la retórica filosófica" en Perelman, Chaïm y Olbrechts Tyteca, Lucie, Tratado de la argumentación jurídica. La nueva retórica. Madrid: Gredos, 2013.

Miaille, Michel, "La especificidad de la forma jurídica burguesa", Crítica Jurídica en Francia, Puebla, Universidad Autónoma de Puebla, 1986.

Nino, Santiago, Introducción al análisis del derecho, Buenos Aires, Astrea, 2003.

Ost, François, El tiempo del Derecho, México, Siglo XX, 2005.

Pashukanis, Evgeny B., Teoría general del derecho y el marxismo, México, Grijalbo, 1976.

Polanyi, Karl, La gran transformación: crítica del liberalismo económico, Barcelona, Virus, 2016.

Portalis, Jean Marie Ettiene, Discurso preliminar al código civil francés, México, Editorial Porrúa, 1998.

Portantiero, Juan Carlos, "Gramsci y el análisis de la coyuntura (algunas notas)", Los usos de Gramsci, Buenos Aires, Grijalbo, 1999.

Poulantzas, Nicos, Hegemonía y dominación en el Estado moderno, Córdoba, Pasado y presente, 1969. Radbruch, Gustav, Introducción a la filosofía del derecho. México, Fondo de Cultura Económica, 2013.

Ramos Colás, Álvaro, "Ciudadano vs consumidor: significado del consumo en el postcapitalismo de Streeck", Oximora. Revista Internacional de Ética y Política, 14, 2019, pp. 91-108 desde: https://doi.org/10.1344/oxi.2019.i14.26641, consultado el 01 de julio de 2020.

Redacción, "Más del 50\% de los mexicanos aprueban gobierno de AMLO, según encuestas". Animal Político, 29 de noviembre de 2019, desde: https://www.animalpolitico.com/2019/11/ aprobacion-gobierno-amlo-encuesta-gabinete-comunicacion-estrategica/ consultado el 07 de mayo de 2020.

Ross, Alf, "El concepto de validez y el conflicto entre el positivismo jurídico y el derecho natural", El concepto de validez y otros ensayos, México, Fontamara, 2008.

Santos, Boaventura de Sousa, A crítica da razão indolente, contra o desperdício da experiencia, Santa Maria da Feira, Afrontamento, 2002.

Santos, Boaventura De Sousa, La globalización del derecho, Bogotá, ILSA, 1998.

Santos, Sociología Jurídica Crítica. Por un nuevo sentido común en el derecho, Madrid, Trotta, 2009. Schiavonne, Aldo, lus, la invención del derecho en occidente, Buenos Aires, Adriana Hidalga, 2013. Schmitt, Carl, El Nomos de la Tierra en el Derecho de Gentes del "Jus Publicum Europeum", Buenos Aires, Struhart \& Cía, 2005.

Secretaría de la Función Pública, Llama Función Pública a aplicar Austeridad Republicana con reducción en el gasto operativo de la APF, desde: https://www.gob.mx/sfp/articulos/llamafuncion-publica-a-aplicar-austeridad-republicana-con-reduccion-en-el-gasto-operativo-de-laapf-240007, consultado el 07 de mayo de 2020.

Tamayo y Salmorán, Rolando, Introducción analítica al estudio del derecho, México, Themis, 2011. Tapia Argüello, Sergio Martín, “Crítica Jurídica y Derechos Humanos: Autonomía normativa, resistencia y Emancipación", Revista Direitos Humans \& Sociedade, 1 (1), 2018.

Tapia Argüello, Sergio Martín, “Derecho laboral e ideología: el liberalismo y la regulación del trabajo en México", Crítica Jurídica. Nueva época, 2, 2020.

Tapia Argüello, "Derecho, modernidad y razón. Reformas y nuevo constitucionalismo en América Latina" en Alvarado Rodríguez, María Eugenia (ed.), Modernidad y derecho en América latina: Acumulación capitalista, desarrollo, naturaleza y movimientos sociales contrahegemónicos, México, Universidad Nacional Autónoma de México, 2018.

Tapia Argüello, Sergio Martín, “El papel del derecho como revolución cultural”, Crítica Jurídica, Revista latinoamericana de política, filosofía y derecho, 32, 2011, pp. 151-59.

Tapia Argüello, Sergio Martín, "El doble papel de los derechos humanos", Conocimiento y cultura jurídica, 5, 2011, desde: https://www.researchgate.net/publication/280815754_El_doble_pa- 
pel_de_los_derechos_humanos, consultado el 6 de mayo de 2020.

Tapia Argüello, Sergio Martín, El sistema internacional de protección de Derechos Humanos, México, Comisión de Derechos Humanos del Distrito Federal, 2013.

Tapia Argüello, Sergio Martín, "Los derechos sociales y el modelo de acumulación flexible en México, Dignitas, V, 2012.

Tapia Argüello, Sergio Martín, “Poder como dominación. Una reducción útil para las visiones tradicionales del derecho", Derecho y Crítica Social, 1 (1), 2015, pp. 411- 446.

Tapia Argüello, Sergio Martín, “Una breve (y quizá personal) introducción a la Crítica Jurídica”, en Tapia Argüello, Sergio Martín; Gómez Martínez, Diego León y Solano Paucay, Vicente, Estudios Jurídicos Críticos en América Latina, Volumen 1, Cali, Diké- Universidad Santiago de Cali, 2019, pp. 127- 160.

Terragni, Marco Antonio, Estudios sobre la parte general del derecho penal, Santa Fe, Centro de Publicaciones- Secretaría de Extensión de la Universidad Nacional del Litoral, 2000.

Thompson, E. P., Los orígenes de la ley negra. Un episodio de la historia criminal inglesa, Buenos Aires, Siglo XXI, 2011.

Tigar, Michell y Levi, Madelaine, El derecho y el ascenso del capitalismo, México, Siglo XXI, 1986. Vázquez, Rodolfo, Entre la libertad y la igualdad. Introducción a la filosofía del Derecho, México, Colofón- Trotta, 2011.

Weber, Max, Economía y sociedad. Esbozo de sociología comprensiva, México, Fondo de Cultura Económica, 2008.

Weber, Max, Historia económica general, México, Fondo de Cultura Económica, 2008.

Weber, Max, "Introducción”, Ensayos sobre sociología de la religión, tomo 1, Madrid, Taurus, 1987. Wensel, Hans, Derecho penal. Parte general, Buenos Aires, Roque Depalma, 1956.

Zizek, Slavoj, En defensa de la intolerancia, Barcelona, Público, 2010. 